\title{
Catalytic Hydrodechlorination of Benzyl Chloride promoted by Rh-NHC Catalysts
}

\author{
Guillermo Lázaro, ${ }^{[\mathrm{a}]}$ Víctor Polo, ${ }^{[\mathrm{b}]}$ Francisco J. Fernández-Alvarez, ${ }^{\text {[a] }}$ Pilar García-Orduña, ${ }^{[\mathrm{a}]}$ Fernando \\ J. Lahoz, ${ }^{[a]}$ Manuel Iglesias, ${ }^{[a]}$ Jesús J. Pérez-Torrente ${ }^{[a]}$ and Luis A. Oro*[a]
}

\begin{abstract}
The rhodium(l) complexes $[\mathrm{Rh}(\mathrm{Cl})(\mathrm{COD})(\mathrm{R}-\mathrm{NHC}$ $\left.\left.\left(\mathrm{CH}_{2}\right)_{3} \mathrm{Si}(\mathrm{OiPr})_{3}\right)\right](\mathrm{COD}=$ cyclooctadiene; $\mathrm{R}=2,6$-diisopropylphenyl (1a); n-butyl (1b)) are effective catalyst precursors for the homogeneous hydrodechlorination of benzyl chloride using $\mathrm{HSiEt}_{3}$ as hydrogen source. This reaction is selective to the formation of toluene. However, in presence of a stoichiometric amount of KtBuO the formation of mixtures containing toluene together with 17-19 mol\% of the $\mathrm{C}-\mathrm{C}$ homocoupling product, namely $\mathrm{PhCH}_{2} \mathrm{CH}_{2} \mathrm{Ph}$, was observed. A mechanism proposal based on experimental insights and theoretical calculations at the DFT level which allows explanation of the experimental findings is included. Moreover, the heterogeneous catalytic system based on the supported catalyst 1aMCM-41 has demonstrated to be effective for the solvent-free hydrodechlorination of benzyl chloride with $\mathrm{HSiEt}_{3}$ and $\mathrm{HSiMe}\left(\mathrm{OSiMe}_{3}\right)_{2}$.
\end{abstract}

\section{Introduction}

The development of new catalytic systems effective for the transformation of hazardous molecules into harmless substances is a relevant goal of sustainable chemistry. ${ }^{[1]}$ In this regard, chloro alkanes in general, and benzyl chloride in particular, have been reported as pollutants ${ }^{[2,3]}$ Therefore, the design of active catalysts for hydrodechlorination of organochlorines is of particular interest. ${ }^{[4,5]}$ The driving force behind hydrodechlorination reaction is the balance between the activation energy of the $\mathrm{E}-\mathrm{H}\left(\mathrm{E}=\mathrm{H}, \mathrm{SiR}_{3}\right)$ and $\mathrm{C}-\mathrm{Cl}$ bonds, and the energy of the new $\mathrm{E}-\mathrm{Cl}$ and $\mathrm{C}-\mathrm{H}$ bonds formed (Scheme 1). Hydrosilanes satisfy both requirements; on one hand $\mathrm{Si}-\mathrm{H}$ bonds can be easily activated by a number of transition metal catalysts $^{[6]}$ and on the other hand silicon and chloride form a strong covalent bond. Additionally, some environmentally innocuous, readily available and easy to handle hydrosilanes have been proposed as potential hydrogen molecular

[a] Dipl.-Chem. G. Lázaro, Dr. F. J. Fernández-Alvarez, Dr. P. GarcíaOrduña, Prof. F. J. Lahoz, Dr. M. Iglesias, Prof. J. J. Pérez-Torrente and Prof. L. A. Oro.

Departamento de Química Inorgánica - Instituto de Síntesis

Química y Catálisis Homogénea (ISQCH)

Universidad de Zaragoza - CSIC

PI. San Francisco S/N, 50009 Zaragoza - Spain

E-mail: paco@unizar.es, oro@unizar.es

[b] Dr. V. Polo

Departamento de Química Física - Instituto de Biocomputación y

Física de Sistemas Complejos (BIFI)

Universidad de Zaragoza

PI. San Francisco S/N, 50009 Zaragoza - Spain storages. ${ }^{[7]}$

$$
\mathrm{E}-\mathrm{H}+\mathrm{R}-\mathrm{Cl} \stackrel{\text { catalyst }}{\longrightarrow} \mathrm{E}-\mathrm{Cl}+\mathrm{R}-\mathrm{H}
$$

Scheme 1. Hydrodechlorination of organic chlorides with hydrosilanes $(E=$ $\left.\mathrm{SiR}_{3}\right)$.

There are some examples of homogeneous catalytic systems based on rhodium complexes which have shown to be effective for catalytic hydrodechlorination of polychloroarenes ${ }^{[\mathrm{a}]}$ and hexachlorocyclohexane ${ }^{[8 \mathrm{~b}]}$ using $\mathrm{HSiEt}_{3}$ as reducing agent. Moreover, $\mathrm{Pd}(\mathrm{II})$ salts have proven to catalyze the reduction of organic chlorides including benzyl chloride with $\mathrm{HSiEt}_{3} .{ }^{[9 a]} \mathrm{P}, \mathrm{P}$. chelated $\mathrm{Pd}(\mathrm{II})$ complexes have been reported as effective homogeneous catalysts for the reduction of organo chlorides using sodium formate as reductor. ${ }^{[\mathrm{b}]}$ In addition, $\mathrm{P}, \mathrm{N}$-chelated $\mathrm{Pt}$ (II) species also behave as active catalysts for the hydrodechlorination of alkyl chlorides with $\mathrm{HSiMe}_{2} \mathrm{Ph}$ as hydrogen source. ${ }^{[10]}$ Recently, Yang and Brookhart have reported a cationic iridium(III) bis(phosphinite) pincer complex which has shown to be highly active for the catalytic reduction of alkyl chlorides to the corresponding alkane by $\mathrm{HSiEt}_{3}{ }^{[11]}$ However, the high price of these scarce precious late-transition metals (Pd, Pt, Rh or Ir) has attracted increasing interest into the design of easily recyclable catalytic systems. In this regard, it is worth noting that heterogeneous catalytic systems based on palladium nanoparticles have found application in hydrodehalogenation of organic halides using aqueous sodium formate $e^{[12 a, b]}$ or molecular hydrogen ${ }^{[12 c-g]}$ as reducing agents. Other heterogeneous catalytic systems based on copper ${ }^{[13 a]}$ or rhodium $^{[13 \mathrm{~b}]}$ nanoparticles and $\mathrm{H}_{2}$ have shown to be active for the reduction of organo chlorides. However, solid catalysts present some disadvantages as for instance: i) are difficult to characterize at the molecular level, and ii) may contain a wide distribution of catalytic sites with different activity and selectivity. One strategy to overcome this drawback could be the covalent immobilization of a single site homogeneous catalyst into an insoluble support to afford a heterogeneized catalyst. ${ }^{[14]}$

By the way, it should be noted that transition metal-NHC complexes with $\mathrm{Si}(\mathrm{OR})_{3}$-functionalized $\mathrm{NHC}$ ligands are easy to immobilize on mineral supports by reaction between the $\mathrm{Si}-\mathrm{OH}$ active sites present on the supports surface and the Si-OR bonds at the substituents of the NHC ligand. ${ }^{[15,16]}$ Particularly, we have recently described the synthesis of $\mathrm{Rh}(\mathrm{NHC})$-based supported catalysts by immobilization of $\mathrm{Si}(\mathrm{O} / \mathrm{Pr})_{3}$-functionalized Rh-NHC ( $\mathrm{NHC}=N$-heterocyclic carbene) complexes on inorganic supports. A previous comparative study has shown that the support plays an important role on the catalytic 
performance of Rh-NHC supported catalyst. Indeed, it has been found that those catalysts prepared with MCM-41 (Figure 1) are more active than those prepared with KIT- 6 or Aerosil as inorganic supoprts. ${ }^{[17 b]}$



Figure 1. Representation of a Rh-NHC catalyst supported on MCM-41.

To the best of our knowledge the application of Rh-NHC catalysts in dehydrochlorination processes has not been studied so far. This work expands the scope of our previous research to explore the potential of Rh-NHC species as catalysts for hydrodechlorination processes. In particular, on the hydrodechlorination of benzyl chloride using hydrosilanes as hydrogen source.

\section{Results and Discussion}

Homogeneously catalyzed hydrodechlorination of benzyl chloride with $\mathrm{HSiEt}_{3}$. Preliminary studies showed that the reactions of 1,4-dioxane solutions of benzyl chloride with $\mathrm{HSiEt}_{3}$ using complex 1a (or 1b) (1.0 mol\%) as catalyst precursor at 70 ${ }^{\circ} \mathrm{C}$ selectively affords toluene in $70 \%$ yield after $16 \mathrm{~h}$. Increasing the catalysts loading up to $2.0 \mathrm{~mol} \%$ and the temperature to 120 ${ }^{\circ} \mathrm{C}$ it was possible to reach the complete conversion of benzyl chloride in 2 hours with excellent selectivity to toluene together with traces of the $\mathrm{C}-\mathrm{C}$ homocoupling product $\mathrm{PhCH}_{2} \mathrm{CH}_{2} \mathrm{Ph}$ (around 3-4 mol\%), as a side reaction product (Table 1, entries 1 and 2). A comparison of both homogeneous catalysts shows that $\mathbf{1 a}$ is slightly more active than $\mathbf{1 b}$ with turnover frequencies (TOF) of 24.0 and $23.5 \mathrm{~h}^{-1}$, respectively. This is in agreement with the tendency observed for acetophenone hydrosilylation, ${ }^{[17 b]}$ and could be attributed to the greater steric influence provided by the 2,6-diisopropylphenyl $\mathrm{N}$-substituent in 1a in comparison with the $n \mathrm{Bu} \mathrm{N}$-substituent in $\mathbf{1 b}$.

It is worth mentioning that ${ }^{1} \mathrm{H}$ NMR studies of the reaction of species 1a (or 1b) with $\mathrm{HSiEt}_{3}$ in $\mathrm{C}_{6} \mathrm{D}_{6}$ evidenced the formation of $\mathrm{Rh}-\mathrm{H}$ containing complexes when the reaction mixture is heated above $70^{\circ} \mathrm{C}$, presumably $\mathbf{2 a}$ (or $\mathbf{2 b}$ ) in Scheme 2 . The formation of these Rh-hydrido species has been proposed as the rate determining step in the catalytic hydrosilylation of acetophenone using $\mathbf{1 a}$ (or $\mathbf{1 b}) \quad(1.0 \mathrm{~mol} \%)$ as catalyst precursor. ${ }^{[17 b]}$ Thus, it is reasonable to assume that the formation of species $\mathbf{2 a}$ (or $\mathbf{2} \mathbf{b}$ ) could also constitute the activation step in the Rh-NHC catalyzed hydrodechlorination processes described in Table 1 (entries 1-6).

Table 1. Homogeneous Rh-catalyzed hydrodechlorination of benzyl chloride with $\mathrm{HSiEt}_{3} .{ }^{\left[{ }^{[a}\right.}$

\begin{tabular}{cccccc}
\hline Entry & catalyst & selectivity $^{[\mathrm{b}]}$ & conversion $^{[\mathrm{c}]}$ & $\mathrm{TON}^{[\mathrm{d}]}$ & $\begin{array}{c}\mathrm{KtBuO} \\
(\mathrm{mmol})\end{array}$ \\
\hline 1 & $\mathbf{1 a}$ & 97.0 & 99.0 & 48.0 & - \\
\hline 2 & $\mathbf{1 b}$ & 96.0 & 98.0 & 47.0 & - \\
\hline 3 & $\mathbf{1 a}$ & 98.5 & 91.0 & 44.8 & 0.03 \\
4 & $\mathbf{1 b}$ & 99.0 & 87.0 & 43.0 & 0.03 \\
5 & $\mathbf{1 a}$ & 65.0 & 86.0 & 28.0 & 1.0 \\
6 & $\mathbf{1 b}$ & 62.0 & 80.5 & 25.0 & 1.0 \\
7 & $\mathbf{6 b}$ & 98.0 & 48.5 & 24.0 & - \\
\hline
\end{tabular}

[a] General reaction conditions: 1,4-dioxane $(1.0 \mathrm{~mL})$, benzyl chloride $(115 \mu \mathrm{L}$ $1.0 \mathrm{mmol}), \mathrm{HSiEt}_{3}(0.8 \mathrm{~mL}, 0.5 \mathrm{mmol}), 2.0 \mathrm{~mol} \%$ of catalyst, hexamenthyl benzene $(4.0 \mathrm{mg})$ as internal standard, $120^{\circ} \mathrm{C}$ and 2 hours of reaction. [b] Selectivity to toluene based on NMR and expressed in $\% \pm 0.5{ }^{[18]}[\mathrm{c}]$ based on NMR and expresed in $\% \pm 0.5$. [d] Turnover number after 2 hours of reaction calculated as [mmol toluene / $\mathrm{mmol}$ of catalyst].
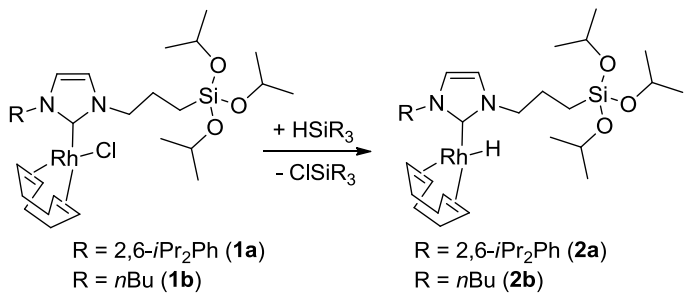

Scheme 2. In situ generation of active $[\mathrm{Rh}(\mathrm{H})(\mathrm{COD})(\mathrm{NHC})]$ species.

Based on that findings we proposed that a $\mathrm{Rh}(\mathrm{I}) / \mathrm{Rh}(\mathrm{III})$ mechanism could be operative for this Rh-catalyzed benzyl chloride hydrodechlorination process (Scheme 3, Path I). In a first step, the reaction of species 1 with $\mathrm{HSiEt}_{3}$ affords the active rhodium(I)-hydrido species 2 which reacts with benzyl chloride to give the $\mathrm{Rh}(\mathrm{III})$ intermediate 3 . The reductive elimination of toluene from 3 regenerates the catalyst precursor 1 . The mechanism proposal showed in Scheme 3 also explains the formation of $\mathrm{PhCH}_{2} \mathrm{CH}_{2} \mathrm{Ph}$ as reaction side product (Scheme 3, Path II). The reductive elimination of toluene or $\mathrm{HCl}$ from the intermediate $\left[\mathrm{Rh}(\mathrm{Cl})(\mathrm{H})\left(\mathrm{CH}_{2} \mathrm{Ph}\right)(\mathrm{COD})\right]$ (3) determines the formation of the hydrodechlorination or $\mathrm{C}-\mathrm{C}$ homocoupling products, that is toluene or 1,2-diphenylethane, respectively. On the other hand the catalytic reactions carried out in the presence of catalytic amounts of $\mathrm{KtBuO}$ leaded to a slight increase of the selectivity of the process but a falloff of the reaction yield (Table 1 , entries 3 and 4 ). Interestingly, using one equivalent of $\mathrm{KtBuO}$ $(0.1 \mathrm{mmol})$ the selectivity of the reaction changes and the concentration of $\mathrm{PhCH}_{2} \mathrm{CH}_{2} \mathrm{Ph}$ increases up to a value of around 
17-19 mol\% (Table 1, entries 5 and 6). This behaviour could be explained by assuming that an excess of $\mathrm{KtBuO}$ promotes $\mathrm{HCl}$ reductive elimination, thus favoring Path II in Scheme 3.

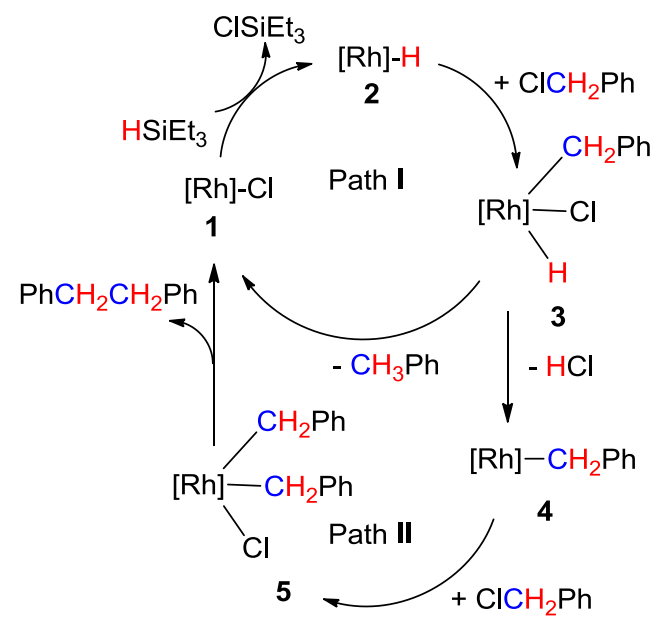

Scheme 3. Mechanism proposal for the Rh-NHC-catalyzed hydrodechlorination of benzyl chloride with $\mathrm{HSiEt}_{3}$.

The decrease of the conversion observed when $\mathrm{KtBuO}$ was added to the reaction mixture suggests a catalyst deactivation process. Indeed, using $\mathbf{1 b}$ as catalyst precursor the conversion drops from $98.0 \%$ (Table 1, entry 2 ) to $80.5 \%$ (Table 1 , entry 6 ). Therefore, we decided to study the reactivity of the less active catalyst precursor, $\mathbf{1 b}$, with $\mathrm{KtBuO}$ in THF. Treatment of $\mathbf{1 b}$ with a stoichiometric amount of $\mathrm{KtBuO}$ in THF affords a brown solution after $24 \mathrm{~h}$ from which compound $\left[\mathrm{Rh}\left\{\mathrm{K}^{2} \mathrm{C}, \mathrm{O}-(n \mathrm{Bu}-\mathrm{NHC}-\right.\right.$ $\left.\left.\left(\mathrm{CH}_{2}\right)_{3} \mathrm{Si}(\mathrm{O} / \mathrm{Pr})_{2} \mathrm{O}-\right\}(\mathrm{COD})\right]$ (6b) was isolated, after purification, as a yellow microcrystalline solid in $60 \%$ yield (see Experimental Section) (Scheme 4). Complex 6b was fully characterized by means of elemental analysis, ${ }^{1} \mathrm{H},{ }^{13} \mathrm{C}\left\{{ }^{1} \mathrm{H}\right\}$ and ${ }^{29} \mathrm{Si}\left\{{ }^{1} \mathrm{H}\right\}$ NMR spectroscopy, mass spectrometry and its molecular structure determined by X-ray diffraction methods. It is worth noting that using $\mathbf{6 b}$ as catalyst precursor under the same reaction conditions used for $\mathbf{1 b}$, in absence of $\mathrm{KtBuO}$, a decrease of the catalytic performance was observed (Table 1, entry 7 ).

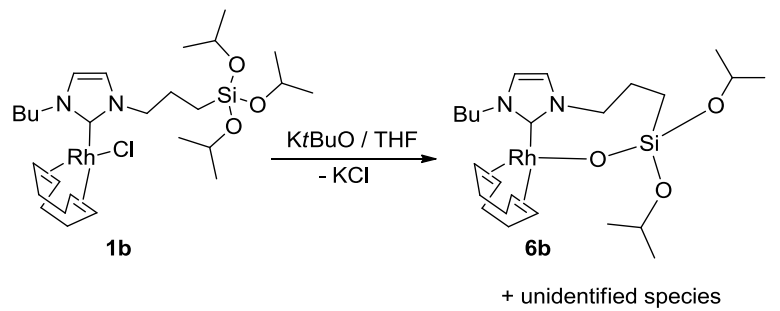

Scheme 4. Reaction of compound $1 \mathbf{b}$ with $\mathrm{KtBuO}$.
The molecular structure of $\mathbf{6 b}$ is depicted in Figure 2, together with the most significant bond lengths and angles. The rhodium atom displays a slightly distorted square planar coordination, with the metal bonded to the two olefinic bonds of the COD ligand in $a \eta^{2}-C=C$ fashion, to the carbon atom $C(15)$ of the $\mathrm{NHC}$ ligand and to the oxygen atom $\mathrm{O}(1)$. The distortion from an ideal square-planar coordination geometry is evidenced by the trans bond angles $\mathrm{O}(1)-\mathrm{Rh}-\mathrm{Ct}(1) \quad 173.67(12)^{\circ}$ and $\mathrm{C}(15)-\mathrm{Rh}-\mathrm{Ct}(2)$ $178.12(14)^{\circ}$ and by the fact that the metal atom lies $0.0514(3) \AA$ out of the mean coordination plane. The imidazol plane is placed almost perpendicular to the mean coordination plane (dihedral angle $\left.81.49(10)^{\circ}\right)$. Geometrical parameters of the fragment $[\mathrm{Rh}(\mathrm{COD})(\mathrm{NHC})]$ compare well with those reported for complexes $\left[\mathrm{Rh}(\mathrm{Cl})(\mathrm{COD})\left(\mathrm{R}-\mathrm{NHC}-\left(\mathrm{CH}_{2}\right)_{3} \mathrm{Si}(\mathrm{O} / \mathrm{Pr})_{3}\right)\right] \quad(\mathrm{R}=2-$ methoxyethy $\left.\right|^{[17 \mathrm{a}]}$ or $\left.2,6-\mathrm{Pr}_{2} \mathrm{Ph}^{[17 \mathrm{~b}]}\right)$.

Interestingly, the $\mathrm{NHC}$ ligand exerts a high structural trans effect producing a significant elongation of the Rh-C bonds situated in relative trans position (mean $\mathrm{Rh}-\mathrm{C}$ bond 2.193(2) $\AA$ ) if compared to those trans to $\mathrm{O}(1)$ atom (mean Rh-C bond 2.101(2) $\AA$ ). This effect, which also influences the olefinic bond distances $(C 1=C 2$ $1.413(5)$ and C5=C6 1.369(5) $\AA$ ), has already been pointed out in related complexes. ${ }^{[17,19 a, 19 b]}$

The $\mathrm{Rh}-\mathrm{O}(1)$ bond distance $(2.056(2) \AA$ ) is in the range of $2.030(2)-2.065(3) \AA$ found for the Rh-OSi bond in $\left[\mathrm{Rh}\left(\mathrm{OSiR}_{3}\right)\left(\mathrm{PCy}_{3}\right)(\mathrm{COD})\right]$ complexes. ${ }^{[20 \mathrm{a}]}$ The coordination of $\mathrm{O}(1)$ atom to the rhodium in $\mathbf{6} \mathbf{b}$ leads to the formation of a 8membered metallacycle. Noteworthy, this leads to a significant shortening of the $\mathrm{Si}-\mathrm{O}(1)$ bond length (1.579(2) $\AA$ ), compared to $\mathrm{Si}-\mathrm{O}(2)$ and $\mathrm{Si}-\mathrm{O}(3)$ values $(1.654(3)$ and $1.648(3) \AA$, respectively) indicating a certain multiple character of this bond However, structural differences between transition metalsiloxides $^{[21]}$ and silanone complexes ${ }^{[22]}$ are quite subtle. It should be noticed that the nature of silicon-chalcogen bonds has recently attracted considerable interest. ${ }^{[23]}$

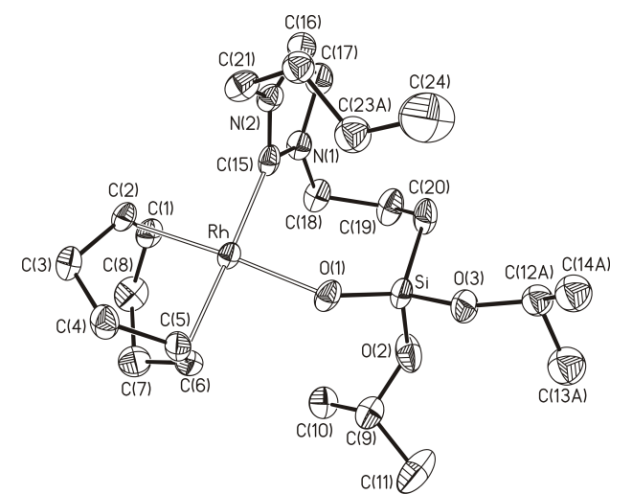

Figure 2. Molecular structure of complex $\mathbf{6 b}$. Hydrogen atoms and the minor components of disordered fragments have been omitted for clarity. Selected bond lengths $(\AA)$ and angles $\left({ }^{\circ}\right)$ : Rh-O(1) 2.056(2), Rh-Ct(1) 1.979(3), Rh-Ct(2) 2.084(3), Rh-C(15) 2.027(4); O(1)-Rh-Ct(1) 173.67(12), O(1)-Rh-Ct(2) 89.80(13), O(1)-Rh-C(15) 91.78(11), Ct(1)-Rh-Ct(2) 87.66(15), Ct(1)-Rh-C(15) 90.88(14), Ct(2)-Rh-C(15) 178.12(14). Ct(1) and $\mathrm{Ct}(2)$ represent the midpoints of the olefinic bonds $C(1)-C(2)$ and $C(5)-C(6)$ bonds, respectively. 
The most relevant resonances in the ${ }^{1} \mathrm{H}$ NMR spectra of $\mathrm{C}_{6} \mathrm{D}_{6}$ solutions of $\mathbf{6 b}$ are those corresponding to the $\mathrm{NCH}_{2}$ protons bounded to $C(18)$, which appear as multiplets at $\delta 5.54$ and 3.60 ppm. Each of these two resonances show a direct $\mathrm{C}-\mathrm{H}$ bond correlation in the heteronuclear single quantum correlation (HSQC) spectra with one signal in the ${ }^{13} \mathrm{C}\left\{{ }^{1} \mathrm{H}\right\}$ NMR spectra, which can be assigned to the $\mathrm{NC}(18)$ carbon atom that appear at $\delta 51.4 \mathrm{ppm}$. The remaining resonances of the ${ }^{1} \mathrm{H}$ and ${ }^{13} \mathrm{C}\left\{{ }^{1} \mathrm{H}\right\}$ spectra are consistent with the structure shown in Figure 2 (see experimental and supporting information). The ${ }^{29} \mathrm{Si}\left\{{ }^{1} \mathrm{H}\right\} \mathrm{NMR}$ spectra of $6 \mathbf{b}$ in $\mathrm{C}_{6} \mathrm{D}_{6}$ exhibit a doublet resonance at $\delta-51.0 \mathrm{ppm}$ $\left({ }^{2} J_{\mathrm{Rh}-\mathrm{Si}}=4.0 \mathrm{~Hz}\right)$ which shows a Si-H correlation in the heteronuclear multiple bond correlation ${ }^{1} \mathrm{H}-{ }^{29} \mathrm{Si} \mathrm{HMBC}$ spectra with the resonances assigned to the $\mathrm{CH}_{2} \mathrm{Si}$ protons bounded to $C(20)$ in the ${ }^{1} \mathrm{H}$ NMR spectra of $6 \mathbf{b}$.

It is noteworthy that the reaction of $\mathbf{1 a}$ with one equivalent of $\mathrm{KtBuO}$ in THF affords a mixture of compounds which contains complex [Rh $\left\{\mathrm{K}^{2} \mathrm{C}, \mathrm{O}-\left(2,6-\mathrm{Pr}_{2} \mathrm{Ph}-\mathrm{NHC}-\left(\mathrm{CH}_{2}\right)_{3} \mathrm{Si}(\mathrm{O} \mathrm{Pr})_{2} \mathrm{O}-\right\}(\mathrm{COD})\right]$ $\mathbf{6 a}$ (related to $\mathbf{6 b}$ ) as major component. All attempts to separate compound $\mathbf{6} \mathbf{a}$ from that mixture of complexes were fruitless.



Figure 3. Relative Gibbs energy profile at $393.15 \mathrm{~K}$ (in $\mathrm{kcal} \mathrm{mol}^{-1}$ ) for the hydrodechlorination of benzylchloride versus the homocoupling reaction using the species $[\mathrm{RhH}(\mathrm{COD})(\mathrm{NHC})](\mathbf{A})\left(\mathrm{NHC}=1,3-N, N^{\prime}\right.$-dimethyl-2-ilydene-imidazol $)$ as catalyst.

Computational studies. Theoretical calculations at the B3LYP. D3 level have been performed on the above described rhodiumcatalyzed hydrodechlorination processes using the complexes $[\mathrm{RhX}(\mathrm{COD})(\mathrm{NHC})]\left(\mathrm{X}=\mathrm{H}(\mathbf{A}), \mathrm{Cl}(\mathbf{E}) ; \mathrm{NHC}=1,3-N, N^{\prime}\right.$-dimethyl2-ilydene-imidazol) as model of species 1 and 2 , respectively (see supporting information).

As a result from these studies it has been found that the formation of toluene and regeneration of species $\mathbf{E}$ from the reaction of $\mathbf{A}$ with benzyl chloride is thermodynamically favored by $53.8 \mathrm{kcal} \mathrm{mol}^{-1}$ (Figure 3). The highest activation barrier of this path, $23.3 \mathrm{kcal} \mathrm{mol}^{-1}$ (TSB/C in Figure 3, see Figure 4 for the molecular geometry), corresponds to the $S_{N} 2$ nucleophilic attack of the metal to the $\mathrm{C}_{\mathrm{sp}}{ }^{3}$ atom of benzyl chloride and concomitant breaking of the $\mathrm{C}_{\mathrm{sp}}{ }^{3}-\mathrm{Cl}$ bond. A metastable ionic pair between the metallic complex of $\mathrm{Rh}$ (III) and the chlorine anion is formed (C). Coordination of the anion to the metal vacancy is energetically favorable being the relative energy of $-17.2 \mathrm{kcal}$ $\mathrm{mol}^{-1}$ and leading to complex D. An alternative reaction mechanism for this step is the concerted $\mathrm{C}_{\mathrm{sp}}{ }^{3}-\mathrm{Cl}$ bond breaking of benzyl chloride and formation of $\mathrm{Rh}-\mathrm{C}$ and $\mathrm{Rh}-\mathrm{Cl}$, however the calculated energetic barrier for this step is much larger that the presented above (see SI).

Starting at intermediate $\mathbf{D}$, two competitive reaction pathways are available. Path I corresponds to the reductive elimination of toluene through TSD/E transition structure (Figure 5) with an activation energy of $11.3 \mathrm{kcal} \mathrm{mol}^{-1}$ to afford the $\mathrm{Rh}(\mathrm{I})$ complex $\mathbf{E}$ (related to 1). Path II leads to the release of $\mathrm{HCl}$ followed by a stepwise mechanism that affords $\mathrm{PhCH}_{2} \mathrm{CH}_{2} \mathrm{Ph}$ and species $\mathbf{E}$. Hence, transition state TSD/F has been found for the migratory insertion of one of the olefin moieties of the COD ligand into the $\mathrm{Rh}-\mathrm{H}$ bond. The activation energy of this process is low $(6.3 \mathrm{kcal}$ $\mathrm{mol}^{-1}$ ) leading to intermediate $\mathbf{F}$. It is worth mentioning that examples of analogous migratory insertions in complexes containing the " $\operatorname{lr}(\mathrm{H})(\mathrm{COD})$ " moiety have been previously reported. ${ }^{[24]}$ In a subsequent step, chlorine anion is dissociated from the metal center and a proton transfer from the $\mathrm{CH}_{2}$ moiety of the ligand to the chlorine anion takes place through TSF/G transition state (Figure 6) showing an activation barrier from the most stable intermediate $\mathbf{D}$ of $14.1 \mathrm{kcal} \mathrm{mol}^{-1}$. After $\mathbf{T S F} / \mathbf{G}$ is passed, $\mathrm{HCl}$ is released and complex $\mathbf{G}$ is obtained. Under the reaction conditions it is reasonable to assume that $\mathrm{HCl}$ reacts 
with the silane to give $\mathrm{ClSiMe}_{3}$ which produces additional stabilization. ${ }^{[25]}$ Path II continues with the coordination of a second molecule of benzyl chloride to the metal through TSH/I with an activation energy of $26.9 \mathrm{kcal} \mathrm{mol}^{-1}$. This process can be described as a $S_{N} 2$ mechanism similar to the one described at $\mathbf{T S B} / \mathbf{C}$, the higher energy is due to the replacement of the hydride by the $\mathrm{CH}_{2} \mathrm{Ph}$ ligand and leads also to a metastable intermediate I. Chlorine coordination to the metal leads to the dibenzylchlorido intermediate $\mathbf{J}$ and, finally, reductive elimination of $\mathrm{PhCH}_{2} \mathrm{CH}_{2} \mathrm{Ph}$ via TSJ/E leads to complex $\mathbf{E}$ closing the catalytic cycle for Path II. Comparison of the highest energetic barriers of path I (TSD/E, $-5.9 \mathrm{kcal} \mathrm{mol}^{-1}$ ) and path II (TSF/G, $3.1 \mathrm{kcal} \mathrm{mol}^{-1}$ ) reveals that the energy barrier for path I is 2.8 $\mathrm{kcal} \mathrm{mol}^{-1}$ lower than the corresponding for path II. This energetic difference is in agreement with the selectivity observed experimentally and with the mechanism proposal shown in Scheme 3 and Figure 3.



Figure 4. Geometrical representation of transition state TSB/C.

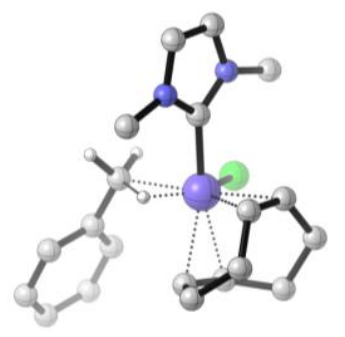

Figure 5. Geometrical representation of transition state TSD/E.

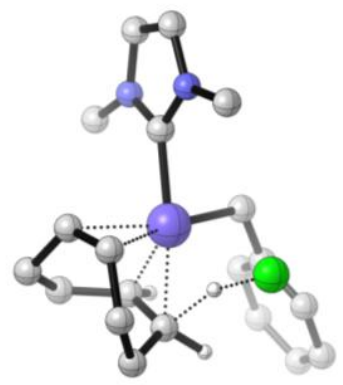

Figure 6. Geometrical representation of transition state TSF/G.

Heterogeneously

Rh-catalyzed hydrodechlorination of benzyl chloride with hydrosilanes. The development of solvent-free catalytic processes is of wide interest in the context of sustainable chemistry. Thus, based on the above described homogeneous catalytic studies we decided to explore the catalytic potential of 1a-MCM-41 (Figure 1) as heterogeneous hydrodechlorination catalyst. This supported catalyst was prepared by reaction of complex 1a with the $\mathrm{Si}-\mathrm{OH}$ actives sites at the surface of MCM-41. ${ }^{[17 b]}$ The resulting solid was characterized by ICP analysis and $\mathrm{N}_{2-}$ physisorption/desorption studies (Table 2). The results of these studies show that the surface area, pore volume and pore diameter of 1a-MCM-41 are lower than the corresponding values obtained for the parent MCM-41, and agree with the anchoring of $1 \mathbf{a}$ inside the channels of the mesoporous material.

Table 2. $\mathrm{N}_{2}$-physisorption/desorption studies and ICP analysis for the support and different preparations of the supported catalyst.

\begin{tabular}{ccccc}
\hline Material & $\mathrm{Rh}(\mathrm{mg} / \mathrm{g})^{[\mathrm{a}]}$ & $\mathrm{SA}\left(\mathrm{m}^{2} / \mathrm{g}\right)^{[\mathrm{b}]}$ & $\mathrm{PD}(\AA))^{[\mathrm{c}]}$ & $\mathrm{PV}\left(\mathrm{cm}^{3} / \mathrm{g}\right)^{[\mathrm{d}]}$ \\
\hline MCM-41 & - & 1070 & 40.9 & 1.00 \\
1a-MCM-41 & 5.12 & 796 & 31.1 & 0.61 \\
1a-MCM-41 & 9.10 & 780 & 31.8 & 0.68 \\
\hline
\end{tabular}

[a] obtained by ICP analysis. [b] Surface area. [c] Pore diameter. [d] Pore volume.

In addition, Transmission Electron Microscopy (TEM) studies of samples of 1a-MCM-41 evidenced that the mesoporous structure of MCM-41 is maintained after the immobilization process (see Figure 7 and supporting information). The only particles that we are able to detect by TEM are those corresponding to MCM-41 and no evidence of Rh particles was observed. This fact constitutes further evidence of the covalent anchoring of the Rh-containing molecules to MCM-41. ${ }^{[15,16]}$ 


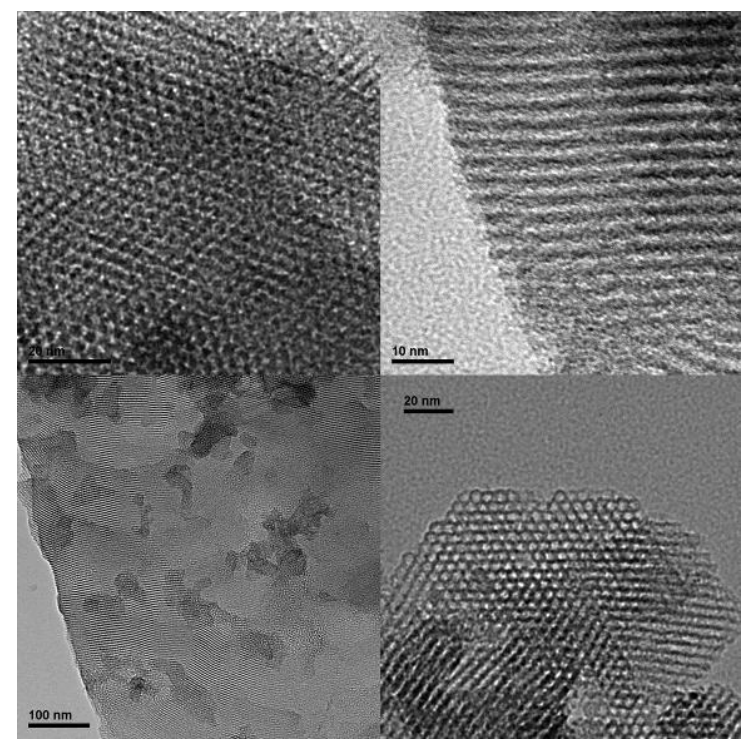

Figure 7. Transmission Electron Microscopy (TEM) images of 1a-MCM-41

The hybrid material 1a-MCM-41 was used as heterogeneous catalyst for the solvent-free hydrodechlorination of benzyl chloride using $\mathrm{HSiEt}_{3}$ or the environmentally innocuous and easily available siloxane $\mathrm{HSiMe}\left(\mathrm{OSiMe}_{3}\right)_{2}$ as hydrogen sources. Interestingly, the results from these studies showed that 1aMCM-41 effectively catalyzed the hydrodechlorination of benzyl chloride (Table 3). However, a slight decrease of the activity in comparison to that achieved by the parent homogenous catalyst, 1a, was observed. Indeed, using the heterogeneous catalyst 1aMCM-41 five hours were needed to accomplish the full transformation of the starting benzyl chloride.

The catalytic activity of the supported catalyst 1a-MCM-41 (Table 3 ) is lower than that reported for catalytic systems based on Pd-nanoparticles and $\mathrm{H}_{2}{ }^{[12 c, 12 g]}$ However, It is worth noting that those Pd-based catalytic systems operate using alcohols as solvent and need excess of base $(\mathrm{NaOH})$ in order to achieve a good performance while the heterogeneous catalyst 1a-MCM-41 presents the advantage of being active under solvent-free conditions. Furthermore, as is shown in Table 3 can be reused after recycling keeping the catalytic activity. It should be mentioned that in all the studied reactions the selectivity values found for the heterogeneous catalyst were slightly higher than those found for the homogeneous reactions (Table 1).
Table 3. Solvent-free heterogeneous Rh-catalyzed hydrodechlorination of benzyl chloride with $\mathrm{HSiEt}_{3}$. ${ }^{\text {a] }}$

\begin{tabular}{cccccc}
\hline Entry & Silane & cycle & selectivity $^{[\mathrm{e}]}$ & conversion $^{[\mathrm{f}]}$ & TON $^{[\mathrm{g}]}$ \\
\hline 1 & $\mathrm{HSiEt}_{3}$ & Fresh $^{[\mathrm{b}]}$ & 100 & 39.91 & 20.0 \\
3 & $\mathrm{HSiEt}_{3}$ & Fresh $^{[\mathrm{c}]}$ & 100 & 59.11 & 12.0 \\
4 & $\mathrm{HSiEt}_{3}$ & Fresh $^{[\mathrm{d}]}$ & 99.5 & 98.0 & 19.5 \\
5 & HSiEt $_{3}$ & $2^{[\mathrm{d}]}$ & 98.0 & 96.0 & 19.0 \\
6 & HSiEt $_{3}$ & $3^{[\mathrm{d}]}$ & 97.5 & 94.0 & 18.5 \\
7 & HSiEt $_{3}$ & $4^{[\mathrm{d}]}$ & 98.0 & 96.5 & 19.0 \\
8 & HMTS $^{[\mathrm{e}]}$ & Fresh $^{[\mathrm{d}]}$ & 100 & 92.0 & 18.5 \\
9 & HMTS $_{10}$ & $2^{[\mathrm{d}]}$ & 100 & 93.0 & 18.5 \\
\hline
\end{tabular}

[a] General reaction conditions: $120 \stackrel{\circ}{ } \mathrm{C}$, benzyl chloride $(11.5 \mu \mathrm{L}, 0.1 \mathrm{mmol})$ silane $(1.0 \mathrm{~mL})$, hexamethyl benzene $(2.0 \mathrm{mg})$ as internal standard. [b] 1aMCM-41 (2.0 mol\%), 2 hours of reaction. [c] 1a-MCM-41 (5.0 mol\%), 2 hours of reaction. [d] 1a-MCM-41 (5.0 mol\%), 5 hours of reaction. [e] Selectivity to toluene based on NMR and expressed in $\% \pm 0.5 .^{[18]}[\mathrm{f]}$ Consumption of benzyl chloride based on NMR and expresed in $\% \pm 0.5$. [g] Turnover number at the end of the reaction calculated as [mmol toluene / $\mathrm{mmol}$ of catalyst]. [e] HMTS $=\mathrm{HSiMe}\left(\mathrm{OSiMe}_{3}\right)_{2}$

\section{Conclusions}

The rhodium(I) complexes $[\mathrm{Rh}(\mathrm{Cl})(\mathrm{COD})(\mathrm{R}-\mathrm{NHC}$ $\left(\mathrm{CH}_{2}\right)_{3} \mathrm{Si}\left(\mathrm{O}_{\left.\left.\left.i \mathrm{Pr}_{3}\right)_{3}\right)\right]}(\mathrm{R}=\right.$ 2,6-diisopropylphenyl (1a); $n \mathrm{Bu}(\mathbf{1 b}))$ are effective catalyst precursors for the homogeneous hydrodechlorination of benzyl chloride to toluene using $\mathrm{HSiEt}_{3}$ as hydrogen source. In presence of one equivalent of $\mathrm{KtBuO}$ the formation of the $\mathrm{C}-\mathrm{C}$ homocoupling product, $\mathrm{PhCH}_{2} \mathrm{CH}_{2} \mathrm{Ph}$, and a decrease of the catalytic performance was observed. A $\mathrm{Rh}(\mathrm{I}) / \mathrm{Rh}$ (III) mechanism, based on theoretical calculations at the DFT level and on experimental insights, has been proposed for explaining the homogeneous hydrodechlorination of benzyl chloride to toluene and the formation of traces of $\mathrm{PhCH}_{2} \mathrm{CH}_{2} \mathrm{Ph}$ as side reaction product. Interestingly, the heterogeneous catalytic system based on the supported catalyst, 1a-MCM-41, has demonstrated to be effective for the solvent-free selective hydrodechlorination of benzyl chloride with $\mathrm{HSiEt}_{3}$ and $\mathrm{HSiMe}\left(\mathrm{OSiMe}_{3}\right)_{2}$

The supported catalyst $\mathbf{1 a - M C M - 4 1}$ is easily handled and it can be stored for long time in air. Furthermore, the heterogeneous catalyst could be reused maintaining the effectivity. In addition, the reducing agent, namely $\mathrm{HSiMe}\left(\mathrm{OSiMe}_{3}\right)_{2}$, which was also used as reaction solvent is environmentally innocuous, cheap and available in ton scale. 


\section{Experimental Section}

General information. All manipulations were performed with rigorous exclusion of air at an argon/vacuum manifold using standard Schlenktube techniques or in a dry-box (MB-UNILAB). Solvents were dried by the usual procedures and distilled under argon prior to use or taken under argon from a Solvent Purification System (SPS). The reagents triethylsilane, $\mathrm{HSiMe}\left(\mathrm{OSiMe}_{3}\right)_{2}$, benzylchloride and the solid MCM-41 were purchased from commercial sources. The complexes $\mathbf{1 a}, \mathbf{1 b}$ and the supported catalyst 1a-MCM-41 were prepared according to methods reported in the literature. ${ }^{[17 b]}$ NMR spectra were recorded on a Varian Gemini 2000, Bruker ARX 300, Bruker Avance $300 \mathrm{MHz}$ or Bruker Avance $400 \mathrm{MHz}$ instrument. Chemical shifts (expressed in parts per million) are referenced to residual solvent peaks $\left({ }^{1} \mathrm{H},{ }^{13} \mathrm{C}\left\{{ }^{1} \mathrm{H}\right\}\right)$. Coupling constants, J, are given in hertz. $\mathrm{C}, \mathrm{H}$, and $\mathrm{N}$ analyses were carried out in a Perkin-Elmer $2400 \mathrm{CHNS} / \mathrm{O}$ analyzer. Mass spectrometry was measured on an Esquire 3000+ with Ion trap detector interfaced to an Agilent 1100 series HPLC system. TEM microscopy images were collected with a INCA 200 X-Sight from Oxford Instruments with a resolution in energy between $136 \mathrm{eV}$ and $5.9 \mathrm{KeV}$. Isotherms were obtained on a Quantachrome AUTOSORB by measuring the volume of $\mathrm{N}_{2}$ absorbed at relative pressures between 0.05 and 0.99 at $77.3 \mathrm{~K}$ after drying the sample at $120^{\circ} \mathrm{C}$ in vacuo. Surface Area Data, pore volume data and pore size data were obtained by Non Localized Density Functional Theory (NLDFT) method.

Homogeneous catalytic reactions. In a MB-UNILAB glove box (argon atmosphere) a cylindrical vessel $(7.5 \mathrm{~mL})$ for operating in batch mode was charged with $\mathrm{HSiEt}_{3}(0.80 \mathrm{~mL}, 5.0 \mathrm{mmol})$, the corresponding catalyst precursor (14.0 mg (1a) or $12.0 \mathrm{mg}$ (1b), $0.02 \mathrm{mmol}), \mathrm{ClCH}_{2} \mathrm{Ph}(115.0 \mu \mathrm{L}$ $1.0 \mathrm{mmol}$ ), $4.0 \mathrm{mg}$ of hexamenthylbenzene as internal standard and 1,4dioxane $(1.0 \mathrm{~mL})$. The vessel was closed, taken out of the glove box and placed in an isothermal bath at $120 \stackrel{\circ}{\circ}$ and continuously stirred for 2 hours, after which the reaction mixture was studied by NMR, quantitative GC and qualitative GC-MS (see supporting information).

Homogeneous catalytic reactions in presence of $\mathrm{KtBuO}$. The procedure for the preparation of the reaction samples was the same as above described for homogeneous catalytic processes but adding $\mathrm{KtBuO}$ (112.0 $\mathrm{mg}, 1.0 \mathrm{mmol}$ or $3.4 \mathrm{mg}, 0.03 \mathrm{mmol}$ ) to the reaction mixture.

Heterogeneous catalytic reactions. The procedure for the preparation of the reaction samples was the same as it was above described for the homogeneous catalytic process but using 1a-MCM-41 (54 mg, Rh loading $9.104 \mathrm{mg} \mathrm{g}^{-1}$ ) as catalyst precursor and the corresponding hydrosilane $(1.0 \mathrm{~mL})$ as solvent and hydrogen source, $\mathrm{ClCH}_{2} \mathrm{Ph}(11.5 \mu \mathrm{L}$, $0.1 \mathrm{mmol}$ ) and $1.6 \mathrm{mg}$ of hexamenthylbenzene as internal standard. Under these reaction conditions we can assume that the reagents and the reaction products have a high diffusion through the channels of 1 aMCM-41. ${ }^{[26]}$

Recycling of the heterogeneous catalyst. After the first catalytic run, the reaction mixture was centrifuged and the corresponding heterogeneous catalyst separated from the product by decantation, washed with $\mathrm{CH}_{2} \mathrm{Cl}_{2}(3 \times 3.0 \mathrm{~mL}), \mathrm{Et}_{2} \mathrm{O}(3 \times 3.0 \mathrm{~mL})$, dried in vacuo and reused without further purifications.

Reaction of $\mathbf{1 b}$ with $\mathrm{KtBuO}$. THF (15 mL) was added to a mixture of $\mathbf{1 b}$ $(50.0 \mathrm{mg}, 0.10 \mathrm{mmol})$ and $\mathrm{K}^{\mathrm{t}} \mathrm{BuO}(11.2 \mathrm{mg}, 0.10 \mathrm{mmol})$. The reaction mixture was stirred at $45{ }^{\circ} \mathrm{C}$ for $16 \mathrm{~h}$. The solvent was removed in vacuo and the residue thus obtained extracted with hexane $(3 \times 10 \mathrm{~mL})$. The hexane solution was concentrated in vacuum to around $5.0 \mathrm{~mL}$ and cooled at $-20^{\circ} \mathrm{C}$ to afford a yellow crystalline solid of $6 \mathbf{b}$. Yield $32 \mathrm{mg}$
(60\%). ${ }^{1} \mathrm{H}$ NMR plus COSY and HSQC $\left(300 \mathrm{MHz}, \mathrm{C}_{6} \mathrm{D}_{6}\right): \delta 6.09\left(\mathrm{~d}, J_{\mathrm{HH}}=\right.$ $\left.2 \mathrm{~Hz}, 1 \mathrm{H}, \mathrm{CH} H_{\text {imd }}\right), 6.08\left(\mathrm{~d}, J_{\mathrm{HH}}=2.0 \mathrm{~Hz}, 1 \mathrm{H}, \mathrm{CH}_{\text {imd }}\right), 5.54(\mathrm{~m}, 1 \mathrm{H}$, $\left.\mathrm{CH}_{2} \mathrm{~N}(3)\right), 5.24\left(\mathrm{~m}, 2 \mathrm{H}, \mathrm{CH}_{\mathrm{COD}}\right), 4.65$ (spt, $J_{\mathrm{HH}}=6.0 \mathrm{~Hz}, 1 \mathrm{H}, \mathrm{CHO} P r$ ), 4.61-4.55 (m, 1H, CH $\left.\mathrm{CH}_{2} \mathrm{~N}(1)\right), 4.38$ (spt, $\mathrm{J}_{\mathrm{HH}}=6.0 \mathrm{~Hz}, 1 \mathrm{H}, \mathrm{CHO} \mathrm{Pr}$ ), 3.86$3.79\left(\mathrm{~m}, 1 \mathrm{H}, \mathrm{CH}_{2} \mathrm{~N}(1)\right), 3.60$ (ddd, $J_{\mathrm{HH}}=13.0,4.0$, and $3.0 \mathrm{~Hz}, 1 \mathrm{H}$, $\left.\mathrm{CH}_{2} \mathrm{~N}(3)\right), 3.08(\mathrm{~m}, 1 \mathrm{H}, \mathrm{CH}$ COD $), 2.79\left(\mathrm{~m}, 1 \mathrm{H}, \mathrm{CH}_{\mathrm{COD}}\right), 2.58-2.48(\mathrm{~m}, 1 \mathrm{H}$, $\left.\mathrm{CH}_{2 \mathrm{COD}}\right), 2.45\left(\mathrm{~m}, 1 \mathrm{H}, \mathrm{CH}_{2 \mathrm{COD}}\right), 2.41-2.33\left(\mathrm{~m}, 1 \mathrm{H}, \mathrm{CH}_{2} \mathrm{CH}_{2} \mathrm{CH}_{3}\right), 2.29(\mathrm{~m}$, $\left.1 \mathrm{H}, \mathrm{CH}_{2 \mathrm{COD}}\right), 2.11\left(\mathrm{~m}, 1 \mathrm{H}, \mathrm{CH}_{2} \mathrm{CH}_{2} \mathrm{Si}\right), 1.98\left(\mathrm{~m}, 1 \mathrm{H}, \mathrm{CH}_{2 \mathrm{COD}}\right), 1.94(\mathrm{~m}, 1 \mathrm{H}$, $\mathrm{CH}_{2 \mathrm{COD}}$ ), $1.90\left(\mathrm{~m}, 1 \mathrm{H}, \mathrm{CH}_{2} \mathrm{CH}_{2} \mathrm{CH}_{3}\right), 1.88-1.79\left(\mathrm{~m}, 1 \mathrm{H}, \mathrm{CH}_{2 \mathrm{COD}}\right), 1.79-$ $1.67\left(\mathrm{~m}, 1 \mathrm{H}, \mathrm{CH}_{2 \mathrm{COD}}+1 \mathrm{H}, \mathrm{CH}_{2} \mathrm{CH}_{2} \mathrm{Si}\right), 1.61\left(\mathrm{~m}, 1 \mathrm{H}, \mathrm{CH}_{2 \mathrm{COD}}\right), 1.52\left(\mathrm{~d}, \mathrm{~J}_{\mathrm{HH}}\right.$ $=6.0 \mathrm{~Hz}, 3 \mathrm{H}, \mathrm{CH}_{3} \mathrm{O}^{\prime} \mathrm{Pr}$ ), $1.47\left(\mathrm{~d}, \mathrm{~J}_{\mathrm{HH}}=6.0 \mathrm{~Hz}, 3 \mathrm{H}, \mathrm{CH}_{3} \mathrm{O} \operatorname{Pr}\right), 1.33(\mathrm{~d}$, $J_{\mathrm{HH}}=6.0 \mathrm{~Hz}, 3 \mathrm{H}, \mathrm{CH}_{3} \mathrm{O}^{\mathrm{i}} \mathrm{Pr}$ ), $1.27\left(\mathrm{~d}, J_{\mathrm{HH}}=6.0 \mathrm{~Hz}, 3 \mathrm{H}, \mathrm{CH}_{3} \mathrm{O}^{\mathrm{i}} \mathrm{Pr}\right.$ ), 1.39$1.15\left(\mathrm{~m}, 2 \mathrm{H}, \mathrm{CH}_{2} \mathrm{CH}_{3}\right), 0.97$ (t, $\left.J=7.0 \mathrm{~Hz}, 3 \mathrm{H}, \mathrm{CH}_{2} \mathrm{CH}_{3}\right), 0.82(\mathrm{~m}, 1 \mathrm{H}$, $\left.\mathrm{CH}_{2} \mathrm{Si}\right), 0.12\left(\mathrm{~m}, 1 \mathrm{H}, \mathrm{CH}_{2} \mathrm{Si}\right) .{ }^{13} \mathrm{C}$ NMR plus APT, HSQC and HMBC (126 $\left.\mathrm{MHz}, \mathrm{C}_{6} \mathrm{D}_{6}\right): \delta 184.5\left(\mathrm{~d}, J_{\mathrm{RhC}}=54.6 \mathrm{~Hz}, \mathrm{NCHN}\right), 120.4\left(\mathrm{CH}_{\text {imd }}\right), 118.8$ $\left(\mathrm{CH}_{\mathrm{imd}}\right), 98.9\left(\mathrm{~d}, \mathrm{~J}_{\mathrm{RhC}}=7 \mathrm{~Hz}, \mathrm{CH}_{\mathrm{COD}}\right), 98.6\left(\mathrm{~d}, J=7 \mathrm{~Hz}, \mathrm{CH}_{\mathrm{COD}}\right), 64.6$ (d, $\left.J_{\mathrm{RhC}}=14 \mathrm{~Hz}, \mathrm{CH}_{\mathrm{COD}}\right), 63.2\left(\mathrm{CH}, \mathrm{O}^{\prime} \mathrm{Pr}\right), 63.1\left(\mathrm{CH}, \mathrm{O}^{\mathrm{i}} \mathrm{Pr}\right), 60.9\left(\mathrm{~d}, \mathrm{~J}_{\mathrm{RhC}}=14\right.$ $\left.\mathrm{Hz}, \mathrm{CH}_{\mathrm{COD}}\right), 51.4\left(\mathrm{CH}_{2} \mathrm{~N}(3)\right), 50.0$ (s, $\left.\mathrm{CH}_{2} \mathrm{~N}(1)\right), 34.7\left(\mathrm{CH}_{2 \mathrm{COD}}\right), 33.5$ $\left(\mathrm{CH}_{2} \mathrm{CH}_{2} \mathrm{CH}_{3}\right), 32.8\left(\mathrm{CH}_{2 \mathrm{COD}}\right), 29.7\left(\mathrm{CH}_{2 \mathrm{COD}}\right), 27.9\left(\mathrm{CH}_{2 \mathrm{COD}}\right), 26.6\left(\mathrm{CH}_{3}\right.$, O'Pr), $26.4\left(\mathrm{CH}_{3}, \mathrm{O}^{\mathrm{i}} \mathrm{Pr}\right), 26.3\left(2 \times \mathrm{CH}_{3}, \mathrm{O}^{\mathrm{i}} \mathrm{Pr}\right), 25.4\left(\mathrm{CH}_{2} \mathrm{CH}_{2} \mathrm{Si}\right), 19.8$ $\left(\mathrm{CH}_{2} \mathrm{CH}_{3}\right), 13.7\left(\mathrm{CH}_{2} \mathrm{CH}_{3}\right), 11.0\left(\mathrm{CH}_{2} \mathrm{Si}\right) .{ }^{29} \mathrm{Si} \mathrm{NMR}\left(60 \mathrm{MHz}, \mathrm{C}_{6} \mathrm{D}_{6}\right): \delta-$ $51.04\left(\mathrm{~d}, \mathrm{~J}_{\mathrm{RhSi}}=4.0 \mathrm{~Hz}\right)$.

X-ray crystal structure determination. Suitable crystals of complex $\mathbf{6 b}$ were grown from a pentane/hexane solution. X-ray data collection was carried out at $100(2) \mathrm{K}$ with graphite-monochromated Mo Ka radiation $(\lambda=$ $0.71073 \AA$ ) using narrow $\omega$ rotations $\left(0.3^{\circ}\right)$ on a Bruker SMART APEX CCD diffractometer. Intensities were integrated with SAINT+ program ${ }^{[27]}$ and corrected for absorption effect with SADABS program ${ }^{[28]}$, integrated in APEX2 package. The structure was solved by direct methods with SHELXS-97. ${ }^{[29]}$ Refinement, by full-matrix least-squares on $F^{2}$, was performed with SHELXL-97. ${ }^{[30]}$

Crystal data for 6 b. $\mathrm{C}_{24} \mathrm{H}_{43} \mathrm{~N}_{2} \mathrm{O}_{3} \mathrm{RhSi}, M=538.61$, yellow prism 0.190 $0.084 \times 0.050 \mathrm{~mm}^{3}$, triclinic, $P-1, a=7.2509(5), b=9.7693(7), c=$

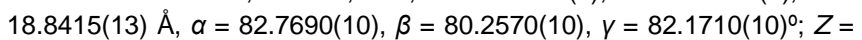
2; $V=1295.90(16) \AA^{3} ; D_{c}=1.380 \mathrm{~g} \mathrm{~cm}^{-3} ; \mu=0.731 \mathrm{~cm}^{-1}$; min. and max. correction factors 0.841 and $0.943 ; 2 \theta_{\max }=52.88^{\circ} ; 13176$ collected reflections, 5267 unique $\left[R_{\text {int }}=0.0313\right]$; number of data /restraints/parameters 5267/1/363; final GoF 1.101; $R_{1}=0.0417$ [4676 reflections, $I>2 \sigma(I)$ ]; $w R_{2}=0.1011$ for all data; the largest difference peak: 1.504 e $\AA^{-3}$. Two carbon atoms of the $n B u$ chain and an isopropyl fragment have been found to be disordered. They have been included in the model in two sets of positions with complementary occupancy factors $(0.511 / 0.489(8)$ and $0.595 / 0.4085(9))$ and isotropically refined. All the hydrogen atoms of the non-disordered parts except those of terminal methyl groups have been included in observed positions and freely refined (with only one restraint in a $\mathrm{C}-\mathrm{H}$ bond length). When convergence

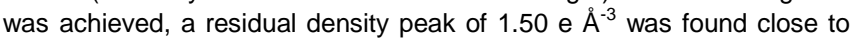
$\mathrm{Rh}$ atom. It has no chemical sense. CCDC 1024308 contains the supplementary crystallographic data for complex $6 \mathbf{b}$. These data can be obtained free of charge from the Cambridge Crystallographic Data Centre via www.ccdc.cam.ac.uk/data request/cif.

Computational details. All DFT theoretical calculations have been carried out using the G09.D01 program package. ${ }^{[31]}$ Full citation is given in supporting information. The B3LYP method ${ }^{[32]}$ has been employed including the D3 dispersion correction proposed by Grimme ${ }^{[33]}$ and the "ultrafine" grid. The def2-SVP basis set ${ }^{[34]}$ has been selected for all atoms for geometry optimizations and calculation of free energy corrections. The nature of the stationary points has been checked by calculation of vibrational frequencies and intrinsic reactions paths have been traced connecting each transition state with the respective intermediates. Solvent effects have been including using the PCM continuum model for 
dichloromethane on the optimized structures. ${ }^{[35]}$ All reported energies are Gibbs energies and relative to $\mathbf{B}$ and isolated molecules.

\section{Acknowledgements}

This work was supported by the Spanish Ministry of Economy and Competitiveness (MINECO/FEDER) (CONSOLIDER INGENIO CSD2009-0050, CTQ2011-27593 and CTQ-201235665 projects, and "Juan de la Cierva" (M.I.) programs) and the DGA/FSE-E07. Dr. F. J. Fernández-Alvarez acknowledges to Prof. Marta Iglesias ICMM-CSIC (Madrid) for preliminary support $\mathrm{Dr}$ V. P. thankfully acknowledges the resources from the supercomputer "Memento", and the technical expertise and assistance provided by the Institute for Biocomputation and Physics of Complex Systems (BIFI) - Universidad de Zaragoza.

Keywords: Rhodium $\cdot$ Hydrodechlorination $\cdot$ Heterogeneous Catalysis $\cdot$ Homogeneous Catalysis $\cdot \mathrm{C}-\mathrm{C}$ homocoupling

[1] a) M. Lancaster in Green Chemistry: An Introductory Text, RSC, Cambridge, 2002. b) P. T. Anastas, M. M. Kirchhoff, Acc. Chem. Res. 2002, 35, 686-694.

[2] R. P. Pohanish in Sittig's Handbook of Toxic and Hazardous Chemicals and Carcinogens, $6^{\text {th }}$ Edition, Elsevier, Waltham, 2012, pp 371-374.

[3] C. E. Smit in Environmental risk limits for benzyl chloride and benzilidene chloride, National Institute for Public Health and the Environment (RIVM) Report 601714016/2010, Bilthoven, 2010.

[4] a) R. L. Lankey, P. T. Anastas, Eds., in Advancing Sustainability through Green Chemistry and Engineering, American Society of Chemistry, Washington D.C., 2002. b) C. Baird, M. Cann in Environmental Chemistry, $4^{\text {th }}$ Edition, W.H. Freeman and Company, New York, 2008

[5] a) F. Alonso, I. P. Beletskaya, M. Yus, Chem. Rev. 2002, 102, 4009 4091. b) S. Jujjuri, E. Ding, E. L. Hommel, S. G. Shore, M. A. Keane, J. Catal. 2006, 239, 486-500. c) C. Douvris, C. M. Nagaraja, C.-H. Chen, B. M. Foxman, O. V. Ozerov, J. Am. Chem. Soc. 2010, 132, 4946-4953 d) M. A. Keane, ChemCatChem 2011, 3, 800-821. e) F. J. FernándezAlvarez, M. Iglesias, L. A. Oro, V. Passarelli, In Bond Activation and Catalysis, Comprehensive Inorganic Chemistry II, Vol. 8. (Eds.: J. Reedijk and K. Poeppelmeier), Elsevier, Oxford, 2013, pp. 399-432.

[6] a) J. Y. Corey, J. Braddock-Wilking, Chem. Rev. 1999, 99, 175-292. b) J. Y. Corey, Chem. Rev. 2011, 111, 863-1071.

[7] a) N. J. Lawrence, M. D. Drew, S. M. Bushell, J. Chem. Soc., Perkin Trans. 1, 1999, 1, 3381-3391. b) W.-S. Han, T.-J. Kim, S.-K. Kim, Y. Kim, Y. Kim, S.-W. Nam, S. O. Kang, Int. J. Hydrogen, Energ., 2011, 36, 12305-12312. c) W. Sattler, G. Parkin, J. Am. Chem. Soc. 2012, 134, 17462-17465. d) K. Garcés, F. J. Fernández-Alvarez, V. Polo, R Lalrempuia, J. J. Pérez-Torrente, L. A. Oro, ChemCatChem, 2014, 6, 1691-1697.

[8] a) M. A. Esteruelas, J. Herrero, F. M. López, M. Martín, L. A. Oro, Organometallics 1999, 18, 1110-1112. b) M. A. Esteruelas, J. Herrero, M. Oliván, Organometallics 2004, 23, 3891-3897.

[9] a) R. Boukherroub, C. Chatgilialoglu, G. Manuel, Organometallics 1996, 15, 1508-1510. b) C. Zhang, X. Li, H. Sun, Inorg. Chim. Acta 2011, 365 133-136.

[10] F. Stöhr, D. Sturmayr, U. Shubert, Chem. Commun. 2002, 2222-2223.

[11] a) J. Yang, M. Brookhart, J. Am. Chem. Soc. 2007, 129, 12656-12657. b) J. Yang, M. Brookhart, Adv. Synth. Catal. 2009, 351, 175-187.

[12] a) Y. M. A. Yamada, T. Waranabe, A. Ohno, Y. Uozumi, ChemSusChem, 2012, 5, 293-299. b) F.-D. Kopinke, D. Angeles-
Wedler, D. Fritsch, K. Mackenzie, Appl. Catal. B: Environ. 2010, 96 323-328. c) T. Hara, T. Kaneta, K. Mori, T. Mitsudome, T. Mizugaki, K. Ebitani, K. Kaneda, Green Chem. 2007, 9, 1246-1251. d) M. A Aramendía, M. Boráu, I. M. García, C. Jiménez, A. Marinas, J. M. Marinas, F. J. Urbano, Appl. Catal. B: Environ. 2003, 43, 71-79. e) Z. Jin, C. Yu, X. Wang, Y. Wan, D. Li, G. Lu, Chem. Commun. 2009 4438-4440. f) J. HongBing, L. QuingPing, H. YungBing, Y. XingDong, Sci. China Chem. 2010, 53, 1520-1524. g) for a review see: F. J. Urbano, J. M. Marinas, J. Mol. Catal. A. Chem. 2001, 173, 329-345.

[13] a) N. Barrabes, D. Cornado, K. Foettinger, A. Dafinov, J. Llorca, F. Medina, G. Rupprechter, J. Catal. 2009, 263, 239-246. b) M. L. Buil, M. A. Esteruelas, S. Niembro, M. Oliván, L. Orzechowski, C. Pelayo, A. Vallribera, Organometallics 2010, 29, 4375-4383.

[14] See for example: A. Corma, H. Garcia, Adv. Synth. Catal. 2006, 348, 1391-1412

[15] a) K. H. Park, S. Kim, Y. K. Chung, Bull. Korean Chem. Soc. 2008, 29, 2057-2060. b) S. Dastgir, K. S. Coleman, M. L. H. Green, Dalton Trans. 2011, 40, 661-672. c) C. S. J. Cazin, M. Veith, P. Braunstein, R. B Bedford, Synthesis 2005, 622-626. d) A. Monge-Marcet, R. Pleixats, X. Cattoën, M. Wong Chi Man, Catal. Sci. Technol. 2011, 1, 1544-1563. e) S. Berardi, M. Carraro, M. Iglesias, A. Sartorel, G. Scorrano, M. Albrecht, M. Bonchio, Chem. Eur. J. 2010, 16, 10662-10666. f) M. Baffert, T. K. Maishal, L. Mathey, C. Copéret, C. Thieuleux ChemSusChem, 2011, 4, 1762-1765. g) K. V. S. Ranganath, S. Onitsuka, A. K. Kumar, J. Inanaga, Catal. Sci. Technol. 2013, 3, 2161 2181.

[16] a) A. Corma, E. Gutiérrez-Puebla, M. Iglesias, A. Monge, S. Pérez Ferreras, F. Sánchez, Adv. Synth. Catal. 2006, 348, 1899-1907. b) A Corma, C. González-Arellano, M. Iglesias, S. Pérez-Ferreras, F. Sánchez, Synlett 2007, 1771-1774. b) C. del Pozo, A. Corma, M. Iglesias, F. Sánchez, Organometallics 2010, 29, 4491-4498. c) G Villaverde, A. Corma, M. Iglesias, F. Sánchez, ChemCatChem 2011, 3 , 1320-1328. d) G. Villaverde, A. Corma, M. Iglesias, F. Sánchez, ACS Catal. 2012, 2, 399-406.

[17] a) G. Lázaro, M. Iglesias, F. J. Fernández-Alvarez, P. J. Sanz Miguel, J. J. Pérez-Torrente, L. A. Oro, ChemCatChem 2013, 5, 1133-1141. b) G. Lázaro, F. J. Fernández-Alvarez, M. Iglesias, C. Horna, E. Vispe, R Sancho, F. J. Lahoz, M. Iglesias, J. J. Pérez-Torrente, L. A. Oro, Cat. Sci. Technol. 2014, 4, 62-70.

[18] Selectivity was calculated applying the following calculation: (B / A) $x$ 100 , where $\mathrm{A}=\mathrm{mol} \%$ of toluene $+\mathrm{mol} \%$ of $\mathrm{PhCH}_{2} \mathrm{CH}_{2} \mathrm{Ph}$ and $\mathrm{B}=$ mol \% of toluene.

[19] a) M. V. Jiménez, J. J. Pérez-Torrente, M. I. Bartolomé, V. Gierz, F. J. Lahoz, L. A. Oro, Organometallics 2008, 27, 224-234. b) M. V. Jiménez, J. Fernández-Tornos, J. J. Pérez-Torrente, F. J. Modrego, S. Winterle, C. Cunchillos, F. J. Lahoz, L. A. Oro, Organometallics 2011, 30, 54935508. c) M. Blanco, P. Álvarez, C. Blanco, M. V. Jiménez, J. Fernández-Tornos, J. J. Pérez-Torrente, L. A. Oro, R. Menéndez, ACS Catal. 2013, 3, 1307-1317.

[20] a) B. Marciniec, P. Błaźejewska-Chadyniak, M. Kubicki, Can. J. Chem 2003, 81, 1292-1298. b) B. Marciniec, I. Kownacki, A. Franczyk, M. Kubicki, Dalton Trans. 2011, 40, 5073-5077

[21] B. Marciniec, H. Maciejewski, Coord. Chem. Rev. 2001, 223, 301-335.

[22] T. Muraoka, K. Abe, Y. Haga, T. Nakamura, K. Ueno, J. Am. Chem. Soc. 2011, 133, 15365-15367.

[23] See for example: a) J. D. Epping, S. Yao, M. Karni, Y. Apeloig, M Driess, J. Am. Chem. Soc. 2010, 132, 5443-5455. b) R. Rodriguez, D Gau, T. Troadec, N. Saffon-Merceron, V. Branchadell, A. Baceiredo, T. Kato, Angew. Chem. Int. Ed. 2013, 52, 8980-8983. c) R. Rodriguez, T. Troadec, D. Gau, N. Saffon-Merceron, D. Hashizume, K. Miqueu, J.-M. Sotiropoulos, A. Baceiredo, T. Kato, Angew. Chem. Int. Ed. 2013, 52, 4426-4430.

[24] a) M. Martín, E. Sola, O. Torres, P. Plou, L. A. Oro, Organometallics 2003, 22, 5406-5417. b) D. H. Nguyen, I. Greger, J. J. Pérez-Torrente, M. V. Jiménez, F. J. Modrego, F. J. Lahoz, L. A. Oro, Organometallics 
2013, 32, 6903-6917. c) D. H. Nguyen, J. J. Pérez-Torrente, M. V. Jiménez, F. J. Modrego, D. Gómez-Bautista, F. J. Lahoz, L. A. Oro, Organometallics 2013, 32, 6918-6930.

[25] a) L. H. Sommer, J. D. Citron, J. Org. Chem. 1967, 32, 2470-2472. b) S Masaoka, T. Banno, M. Ishikawa, J. Organomet. Chem. 2006, 691, 174-181. c) R. Savela, W. Zawarta, R. Leino, Organometallics 2012, 31 3199-3206.

[26] a) L. Gjerdåker, D. W. Aksnes, G. H. Sørland, M. Stöcker, Micropor. Mesopor. Mat. 2001, 42, 89-96. b) F. Courivaud, E. W. Hansen, S Kolboe, A. Kerlsson, M. Stöcker, Micropor. Mesopor. Mat. 2000, 37, 223-232.

[27] SAINT+, Version 6.01: Area-Detector Integration Software, Bruker AXS, Madison, WI, 2001.
[28] SADABS, Area-Detector Absorption Correction Program, Bruker AXS, Madison, WI, 1996.

[29] G. M. Sheldrick, Acta Crystallogr. 1990, A46, 467-473.

[30] a) G. M. Sheldrick, Methods Enzymol. 1997, 276, 628-641. b) G. M. Sheldrick, Acta Crystallogr. 2008, A64, 112-122.

[31] Gaussian 09, Revision D.01, M. J. Frisch et al.

[32] a) C. Lee, W. Yang, W, R. G. Parr, Phys. Rev. B 1988, 37, 785-789. b) A. D. Becke, J. Chem. Phys. 1993, 98, 1372-1377. c) A. D. Becke, J. Chem. Phys. 1993, 98, 5648-5652.

[33] S. Grimme, J. Antony, S. Ehrlich, H. Krieg J. Chem. Phys. 2010, 132, 154104-154119.

[34] F. Weigend, R. Ahlrichs, Phys. Chem. Chem. Phys. 2005, 7, 3297-3305

[35] J. Tomasi, B. Mennucci, R. Cammi, Chem. Rev. 2005, 105, 2999-3094. 
